\title{
Finding Jobs in Political Science: 1996 Placement Candidates Report on Their Employment Search and Outcomes
}

\author{
Sheilah Mann, American Political Science Association
}

Thenter he American Political Science has been participating in a project funded by the National Science Foundation that examines the employment of recent Ph.D.s. The project, "Supply and Demand for New Science and Engineering Doctorates, " coordinated by the Commission on Professionals in Science and Technology (CPST), was initiated with a grant from the Sloane Foundation and examined the placement of doctoral graduates in science and engineering professions. NSF has supported the expansion of the project to include additional scientific and technical associations including the American Psychological Association, the American Sociological Association, and APSA. Information about the project and data from the other participating professional associations can be found on the CPST web site (www.nextwave.org/ survey13.htm).

The major APSA activity for this collaborative project was a survey of the doctoral graduates in political science who were looking for jobs in 1996. This essay discusses data collected from respondents to the survey. These data provide the first direct account by political science placement candidates of their job search experiences and their evaluation of the resources they used in seeking employment. Their experiences, augmented by comments on what was and would be useful in the job search should encourage and inform graduate departments and APSA, along with other political science associations, Organized Sections, and caucuses on how to better assist graduate students in planning their careers and getting jobs in political science. Appendix 1 describes how this survey was conducted.

An examination of the profile of the 1996 placement candidates who responded to the survey begins this discussion of placement in political science. Specific aspects of their employment search and its outcome, along with their employment and career satisfaction, are explored next, followed by information on the job search experiences and outcomes of the placement candidates in dualcareer situations (i.e., candidates with a spouse or partner who is also looking for employment) as compared with that of their cohorts without dual-career needs. A summary of what the respondents now regard as useful in preparing them to find jobs and would recommend to future graduates as they prepare for their job search precedes recommendations for how departments and professional organizations might better assist doctoral students preparing for political science careers. This article has six of the sixteen tables that elaborate on the respondents' experiences and assessments of their search for employment. Collectively, these tables display data on all questions in the survey. Appendix 2 lists the other ten tables that draw upon these same questions and whose findings are summarized in the essay. These ten tables can be found on the APSA website (www.apsanet. org/professional/placement). ${ }^{1}$

\section{Placement Candidates: Their Job Search and Its Outcomes}

The attributes of the doctoral graduates on the job market in 1996 are summarized in Table 1 . The composition of respondents is similar to the profile of the 1996 placement class drawn from the data submitted by Ph.D. departments (Mann 1996). ${ }^{2}$ A slightly smaller percentage of respondents are not U.S. citizens, most likely attributable to their return their home countries for employment. Twenty-seven percent of the survey respondents are women, and women were $29 \%$ of the job candidates in the 1996 departmental placement survey. African-American and Latino graduates were each $2 \%$ of the respondents to this survey in comparison with $2.8 \%$ and $1.6 \%$ of the earlier departmental survey. Table 1 also displays information about the personal attributes of 1996 political science doctoral graduates. Their median age is 32 ; close to two-thirds are married or in domestic partnerships: $32 \%$ have children, and over half are in dual-career situations. Nine percent of the placement candidates have spouses or partners needing placement in political science and another $11 \%$ have spouses or partners needing placement in another academic field.

There are some notable differences between the respondents and the placement candidates studied earlier: a greater percentage of these respondents have their degrees $(80 \%$ compared to $57 \%$ ) and a greater percentage have jobs ( $87 \%$ to $65 \%$ ). But, these differences may be attributable to the later administration in 


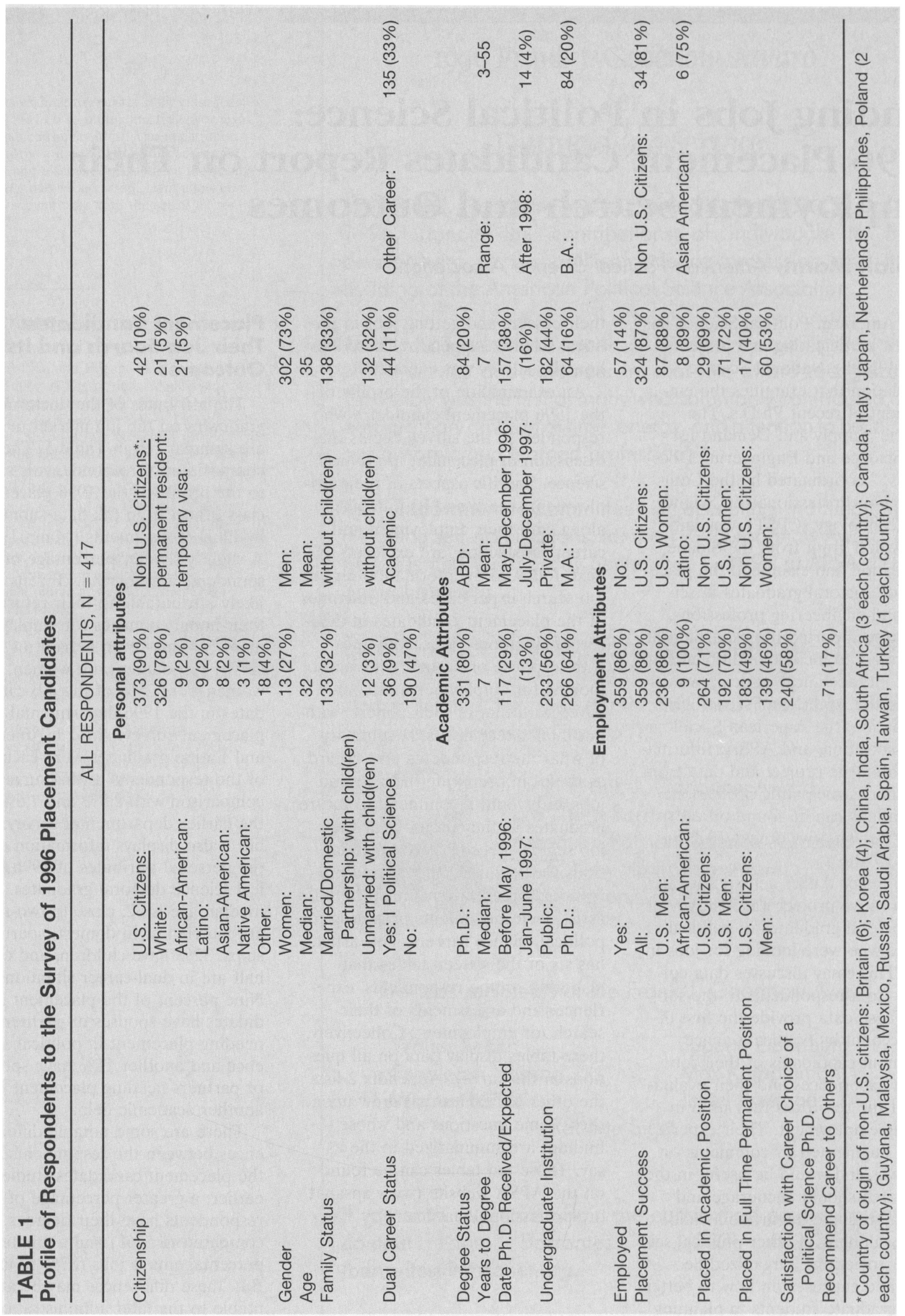




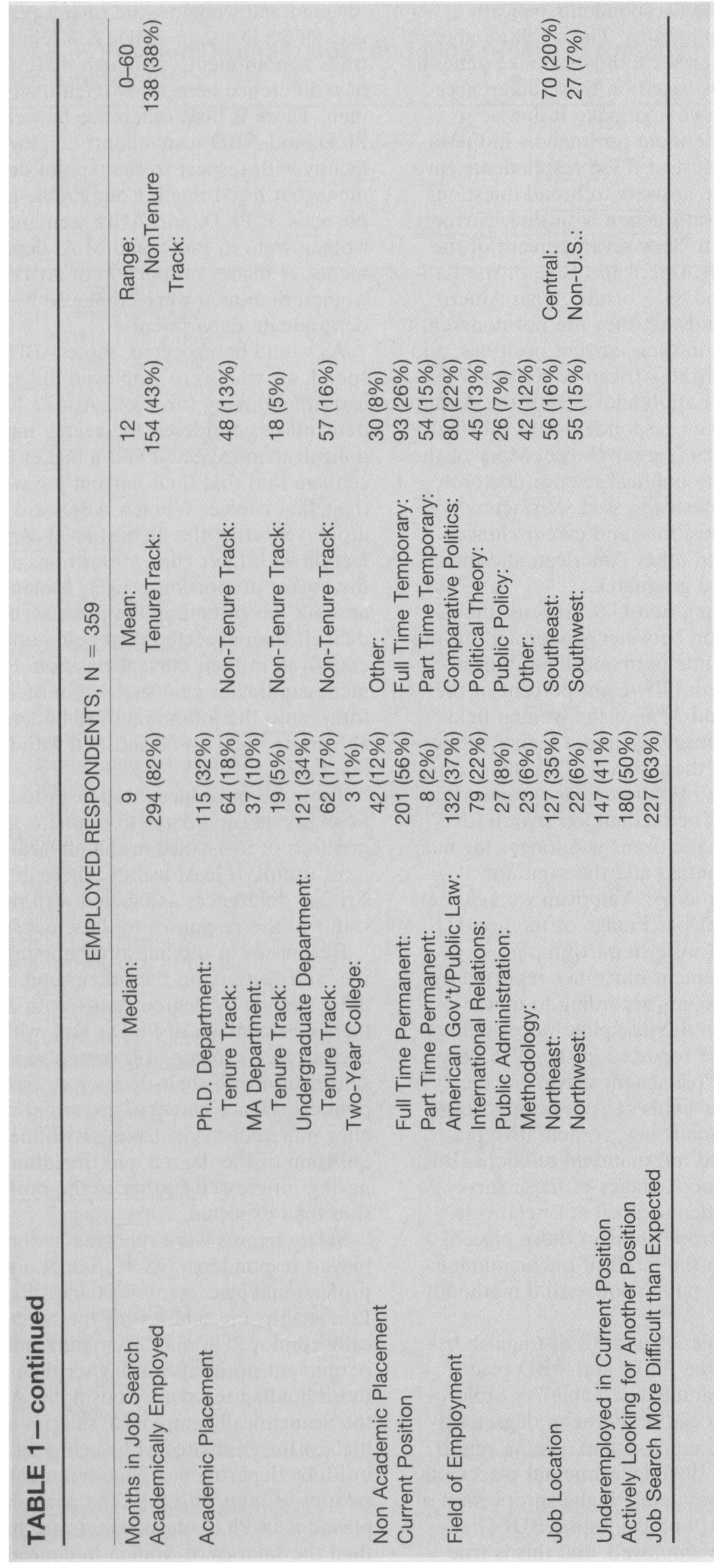

the 1996-97 academic year of the direct survey of job candidates. Twenty-nine percent of these respondents received their degrees in 1997 after departments completed and returned their placement questionnaires. Also, placement candidates continued to receive and accept job offers in the winter and spring of 1997.

The higher overall proportion of placed job candidates should not lead to much optimism about the job market or the job search. Seventyone percent of these candidates had academic positions, but only $37 \%$ had tenure-track appointments; and less than half of all of the respondents $(48 \%)$ had full-time permanent positions. A higher percentage of U.S. citizens ( $49 \%$ ) than non-citizens $(40 \%)$ had full-time permanent jobs. A slightly higher percentage of women $(53 \%)$ were appointed to full-time permanent positions than men $(46 \%)$. Almost three-fifths of the placement candidates $(58 \%)$ said that they are satisfied with their pursuit of a Ph.D. and a career in political science and only $14 \%$ are not satisfied. In contrast with satisfaction with their own career choice, only $17 \%$ of them would recommend the career to others, with the remaining $83 \%$ evenly divided between uncertainty and not recommending a political science career. Their assessments likely reflect the immediacy and difficulty of their own job search, and are associated with the length of time of their job search. Seventy-one percent of the respondents who spent six months or less looking for a job expressed satisfaction with choosing a political science, career and $26 \%$ would recommend the career to others. In sharp contrast, $37 \%$ of the respondents who searched for employment for over two years before being hired affirmed that they are satisfied with their career choice, and only $7 \%$ of these political scientists would recommend the career to others. It is worth pointing out that $97 \%$ of the graduates with this lengthy job search received their doctorate.

Table 1 also profiles the employed respondents. Eighty-two percent of the employed respondents received 
academic appointments, with only 43\% appointed to tenure track positions. Fully one-half reported that they are actively looking for another job, $41 \%$ considered themselves underemployed, and nearly two-thirds considered their job search was more difficult than expected. Among the respondents who held academic positions, comparable percentages have tenure- and nontenure-track positions. Only $32 \%$ of these newly employed doctoral graduates were placed in Ph.D. departments, whereas two thirds of them began their careers working in institutions with differing missions from that of their graduate institutions. As $64 \%$ of the respondents earned their undergraduate degrees from $\mathrm{Ph} . \mathrm{D}$. departments, many new political science faculty have had no direct prior experience with the kind of institutions in which they were placed. Since comprehensive universities, public and private colleges, and community colleges now constitute the majority of hiring institutions in higher education, doctoral students would be well advised to learn about and have contact with non-Ph.D. institutions (Gaff and Lambert 1996).

Table 2 has more data on the placement outcomes for the employed respondents, by citizenship, gender, and minority status. A higher percentage of U.S. women $(66 \%)$ than men $(53 \%)$ held fulltime permanent positions and tenure-track positions ( $66 \%$ of the women and $47 \%$ of the men). A slightly higher percentage of women $(39 \%)$ than men $(34 \%)$ were employed in undergraduate departments. While all of the AfricanAmerican respondents were employed, fewer were in permanent positions than were Latino and Asian-American respondents and women. But, a higher proportion of the employed African Americans had appointments in Ph.D. departments than did any other group of respondents. The few African-American respondents spent the least time in the job search of any group-a median time of 5 months. Women, typically, spent 8 months looking for a job, and male, Latino, and Asian-
American respondents typically spent 9 months. The small number of minority candidates make generalizations based on these differences unreliable and make it unwise to separate them for analysis in the tables. Most of these respondents gave positive answers to broad questions about satisfaction with their current position. Sixty-seven percent of the African Americans, $63 \%$ of the Latinos, and $83 \%$ of the Asian Americans said that they are not underemployed in their current positions, and $67 \%$ of the African-American, $78 \%$ of the Latino and $75 \%$ of the AsianAmerican respondents are satisfied with their career choice. More of the minority political science doctoral graduates expressed satisfaction with their positions and career choices than did other American and international graduates.

Among non-U.S. citizens, the association between gender and having a full-time permanent position is reversed. Fifty-eight percent of the men and $33 \%$ of the women held these positions, and a higher proportion of these men (62\%) than women $(43 \%)$ were on a tenure track. The median job search for non-U.S. citizens was longer for men (10 months) and the same for women as for American women, but a higher percentage of the non-U.S. women were in part-time jobs.

Placement outcomes reported by respondents according to major fields in the discipline were similar to those reported in the 1996 departmental placement survey for the broader fields of American government/public law, comparative politics, and international relations. But larger percentages of these survey respondents, albeit still relatively small proportions of those placed, were in the fields of public administration, public policy, and methodology.

Tables $3 \mathrm{~A}$ and $3 \mathrm{~B}$ distinguish between the Ph.D. and ABD placement candidates. Table 3A explores the association between degree status and employment. As the report on the 1996 departmental placement data revealed, a higher proportion of Ph.D.s ( 9 of 10) than ABDs ( 7 of $10)$ are employed, and this is true for men and women. And higher percentages of Ph.D.s than ABDs had tenuretrack appointments, although there is less of a difference here for women than for men. There is little difference between Ph.D. and ABD respondents employed as faculty with respect to the type of department that hired them: Comparable proportions of Ph.D. and ABD men and women were in Ph.D. and M.A. departments. A higher proportion of ABD women than men were employed by undergraduate departments.

As would be expected, those ABD respondents who were employed did spend less time looking for a job. Also, a lower percentage considered the search more difficult than expected and a higher percentage said that their current job was their first choice. Women ABDs are the group reporting the highest level of satisfaction with their current positions and the lowest proportion actively looking for another job or finding the job search more difficult than expected, and being underemployed in their current position. Placement candidates who succeed in their first forays into the job market are understandably more likely to be satisfied with the outcome.

Table 3B introduces responses to questions asking candidates to evaluate specific methods of assistance in the job search as most useful or least useful. There are no striking differences associated with degree status in the responses to these questions.

Responses to the questions about career satisfaction, on the other hand, do differ slightly by degree status, with a higher percentage of Ph.D.s and, within each degree category, of women reporting satisfaction with their decision to pursue a political science career. The former difference may reflect satisfaction with the acquisition of the degree and the latter with having progressed further in the profession than expected.

Salary figures were reported by the employed respondents (www.apsanet.org/ professional/placement/webtable1.html). ${ }^{3}$ Predictably, the salaries for the academically employed graduates holding full-time permanent positions are higher than for those holding temporary positions. Among the academically employed, salaries are highest for graduates with such positions in Ph.D. departments. Nine-ten month salaries of men with full-time permanent positions in $\mathrm{Ph} . \mathrm{D}$. departments are higher than the salaries of women in equivalent 


\section{TABLE 2}

Type of Position, Primary Job, and Major Field of Employment for 1996 Placement Candidates Who Are Employed*

\begin{tabular}{|c|c|c|c|c|c|c|c|c|c|}
\hline & \multicolumn{6}{|c|}{$N=359$} & \multirow{2}{*}{\multicolumn{3}{|c|}{ Non U.S. Citizens }} \\
\hline & \multicolumn{6}{|c|}{ U.S. Citizens } & & & \\
\hline & $\frac{\text { All }}{N=324}$ & $\frac{\text { Men }}{N=236}$ & $\frac{\text { Women }}{N=87}$ & $\begin{array}{c}\text { African } \\
\text { American } \\
N=9\end{array}$ & $\frac{\text { Latino }}{N=8}$ & $\begin{array}{c}\begin{array}{c}\text { Asian } \\
\text { American }\end{array} \\
\mathrm{N}=6\end{array}$ & All & $\frac{\text { Men }}{N=25}$ & $\frac{\text { Women }}{N=9}$ \\
\hline \multicolumn{10}{|l|}{ Type of Position } \\
\hline Full Time Permanent & $57 \%$ & $53 \%$ & $66 \%$ & $44 \%$ & $63 \%$ & $67 \%$ & $52 \%$ & $58 \%$ & $33 \%$ \\
\hline Full Time Temporary & 26 & 28 & 22 & 33 & 12 & 17 & 27 & 29 & 22 \\
\hline Part Time Permanent & 2 & 2 & 1 & 0 & 0 & 0 & 3 & 0 & 11 \\
\hline Part Time Temporary & $\frac{15}{102}$ & 17 & $\frac{11}{1000}$ & 22 & 25 & $\frac{17}{1010}$ & 18 & 13 & 33 \\
\hline \multicolumn{9}{|l|}{ Academically Employed } & $99 \%$ \\
\hline Yes & $83 \%$ & $83 \%$ & $82 \%$ & $100 \%$ & $75 \%$ & $83 \%$ & $85 \%$ & $84 \%$ & $89 \%$ \\
\hline No & 17 & 17 & 18 & 0 & 25 & 17 & 15 & 16 & 11 \\
\hline Total & $\overline{100} \%$ & $\overline{100} \%$ & $\overline{100} \%$ & $\overline{100} \%$ & $\overline{100} \%$ & $\overline{100} \%$ & $\overline{100} \%$ & $\overline{100} \%$ & $\overline{100} \%$ \\
\hline \multicolumn{10}{|l|}{ Tenure Track } \\
\hline Yes & $52 \%$ & $47 \%$ & $66 \%$ & $44 \%$ & $67 \%$ & $60 \%$ & $57 \%$ & $62 \%$ & $43 \%$ \\
\hline No & 48 & 53 & 34 & 56 & 33 & 40 & 43 & 38 & 57 \\
\hline Total & $\overline{100} \%$ & $\overline{100} \%$ & $\overline{100} \%$ & $\overline{100} \%$ & $\overline{100} \%$ & $\overline{100} \%$ & $\overline{100} \%$ & $\overline{100} \%$ & $\overline{100} \%$ \\
\hline \multicolumn{10}{|l|}{ Type of Primary Job } \\
\hline Ph.D. Department & $33 \%$ & $34 \%$ & $32 \%$ & $67 \%$ & $29 \%$ & $50 \%$ & $32 \%$ & $29 \%$ & $43 \%$ \\
\hline MA Department & 10 & 10 & 10 & 22 & 14 & 0 & 19 & 21 & 14 \\
\hline Undergrad Department & 35 & 34 & 39 & 11 & 43 & 33 & 26 & 25 & 29 \\
\hline Two-Year College & 1 & 1 & 0 & 0 & 0 & 0 & 0 & 0 & 0 \\
\hline Non-Academic Position & 12 & 12 & 12 & 0 & 14 & 17 & 13 & 13 & 14 \\
\hline Other & 9 & 9 & 7 & $\underline{0}$ & 0 & 0 & 10 & 12 & 0 \\
\hline Total & $\overline{100} \%$ & $\overline{100} \%$ & $\overline{100} \%$ & $\overline{100} \%$ & $\overline{100} \%$ & $\overline{100} \%$ & $\overline{100} \%$ & $\overline{100} \%$ & $\overline{100} \%$ \\
\hline \multirow{2}{*}{\multicolumn{10}{|c|}{$\frac{\text { Months Spent Looking for }}{\text { Job }}$}} \\
\hline & & & & & & & & & \\
\hline Median & 9 & 9 & 8 & 5 & 9 & 9 & 10 & 10 & 8 \\
\hline Mean & 12 & 13 & 11 & 8 & 10 & 9 & 12 & 12 & 11 \\
\hline \multicolumn{10}{|l|}{ Field of Employment ${ }^{\star *}$} \\
\hline $\begin{array}{l}\text { American Gov't/Public } \\
\text { Law }\end{array}$ & $33 \%$ & $37 \%$ & $41 \%$ & $44 \%$ & $50 \%$ & $17 \%$ & $21 \%$ & $16 \%$ & $33 \%$ \\
\hline Public Policy & 8 & 9 & 6 & 0 & 0 & 0 & 0 & 0 & 0 \\
\hline Comparative Politics & 21 & 23 & 17 & 11 & 38 & 33 & 32 & 28 & 44 \\
\hline International Relations & 20 & 23 & 14 & 0 & 13 & 0 & 41 & 48 & 22 \\
\hline Public Administration & 8 & 6 & 14 & 44 & 0 & 0 & 3 & 4 & 0 \\
\hline Political Theory & 14 & 15 & 9 & 0 & 0 & 17 & 3 & 4 & 0 \\
\hline Methodology & 7 & 7 & 6 & 0 & 0 & 0 & 6 & 8 & 0 \\
\hline Other & 11 & 11 & 10 & 22 & 0 & 17 & 18 & 20 & 11 \\
\hline \multirow{2}{*}{\multicolumn{10}{|c|}{$\frac{\text { Field in Which Sought }}{\text { Employment }^{\star \star}}$}} \\
\hline & & & & & & & & & \\
\hline $\begin{array}{l}\text { American Gov't/Public } \\
\text { Law }\end{array}$ & $35 \%$ & $34 \%$ & $36 \%$ & $44 \%$ & $50 \%$ & $17 \%$ & $9 \%$ & $8 \%$ & $11 \%$ \\
\hline Public Policy & 8 & 8 & 8 & 22 & 25 & 0 & 6 & 0 & 22 \\
\hline Comparative Politics & 23 & 24 & 21 & 22 & 50 & 33 & 56 & 48 & 78 \\
\hline International Relations & 20 & 22 & 14 & 11 & 25 & 0 & 47 & 52 & 33 \\
\hline Public Administration & 7 & 6 & 10 & 33 & 0 & 0 & 3 & 4 & 0 \\
\hline Political Theory & 14 & 15 & 10 & 11 & 13 & 17 & 3 & 4 & 0 \\
\hline Methodology & 4 & 6 & 1 & 0 & 0 & 0 & 9 & 12 & 0 \\
\hline Other & 9 & 9 & 11 & 0 & 0 & 0 & 15 & 20 & 0 \\
\hline
\end{tabular}

${ }^{*}$ All valid responses.

${ }^{* *}$ Respondents could select all fields that apply in this table and in all the tables reporting on field of employment or field in which sought employment. 
TABLE $3 A$

1996 Placement Candidates: Degree Status and Employment*

\begin{tabular}{|c|c|c|c|c|c|c|c|c|c|}
\hline & \multicolumn{3}{|c|}{ All Candidates } & \multicolumn{3}{|c|}{ Ph.D. } & \multicolumn{3}{|c|}{$A B D$} \\
\hline & All & Men & Women & All & Men & Women & All & Men & Women \\
\hline & $\overline{N=417}$ & $\bar{N}=302$ & $\bar{N}=113$ & $\bar{N}=331$ & $\bar{N}=244$ & $\bar{N}=86$ & $\bar{N}=84$ & $\bar{N}=58$ & $\bar{N}=26$ \\
\hline \multicolumn{10}{|l|}{ Employed } \\
\hline Yes & $86 \%$ & $86 \%$ & $86 \%$ & $90 \%$ & $90 \%$ & $91 \%$ & $70 \%$ & $71 \%$ & $69 \%$ \\
\hline No & 14 & 14 & 14 & 10 & 10 & 9 & 30 & 29 & 31 \\
\hline Total & $\overline{100} \%$ & $\overline{100} \%$ & $\overline{100} \%$ & $\overline{100} \%$ & $\overline{100} \%$ & $\overline{100} \%$ & $\overline{100} \%$ & $100 \%$ & $\overline{100} \%$ \\
\hline \multicolumn{10}{|l|}{ Academically Employed } \\
\hline Yes & $83 \%$ & $83 \%$ & $83 \%$ & $82 \%$ & $83 \%$ & $80 \%$ & $85 \%$ & $80 \%$ & $94 \%$ \\
\hline No & 17 & 17 & 17 & 18 & 17 & 20 & 15 & 20 & 6 \\
\hline Total & $\overline{100} \%$ & $\overline{100} \%$ & $\overline{100} \%$ & $\overline{100} \%$ & $\overline{100} \%$ & $\overline{100} \%$ & $\overline{100} \%$ & $\overline{100} \%$ & $\overline{100} \%$ \\
\hline \multicolumn{10}{|l|}{ Tenure Track } \\
\hline Yes & $53 \%$ & $48 \%$ & $64 \%$ & $55 \%$ & $52 \%$ & $65 \%$ & $40 \%$ & $30 \%$ & $59 \%$ \\
\hline No & 47 & 52 & 36 & 45 & 48 & 35 & 60 & 70 & 41 \\
\hline Total & $\overline{100} \%$ & $\overline{100} \%$ & $\overline{100} \%$ & $\overline{100} \%$ & $\overline{100} \%$ & $\overline{100} \%$ & $\overline{100} \%$ & $\overline{100} \%$ & $\overline{100} \%$ \\
\hline \multicolumn{10}{|l|}{ Type of Position } \\
\hline Full Time Permanent & $57 \%$ & $54 \%$ & $63 \%$ & $58 \%$ & $56 \%$ & $64 \%$ & $49 \%$ & $44 \%$ & $61 \%$ \\
\hline Full Time Temporary & 26 & 28 & 22 & 28 & 30 & 22 & 19 & 17 & 22 \\
\hline Part Time Permanent & 2 & 2 & 2 & 1 & 1 & 3 & 7 & 10 & 0 \\
\hline Part Time Temporary & 15 & 16 & 13 & 13 & 14 & 12 & 25 & 29 & 17 \\
\hline Total & $\overline{100} \%$ & $\overline{100} \%$ & $\overline{100} \%$ & $\overline{100} \%$ & $\overline{101} \%$ & $\overline{101} \%$ & $\overline{100} \%$ & $\overline{100} \%$ & $\overline{100} \%$ \\
\hline \multicolumn{10}{|l|}{ Type of Primary Job } \\
\hline Ph.D. Department & $33 \%$ & $33 \%$ & $33 \%$ & $33 \%$ & $34 \%$ & $32 \%$ & $32 \%$ & $32 \%$ & $33 \%$ \\
\hline MA Department & 11 & 11 & 10 & 10 & 11 & 10 & 12 & 12 & 11 \\
\hline Undergrad Department & 35 & 33 & 39 & 35 & 34 & 37 & 34 & 27 & 50 \\
\hline Two-Year College & 1 & 1 & 0 & 0 & 0 & 0 & 3 & 5 & 0 \\
\hline Non-Academic Position & 12 & 12 & 12 & 12 & 11 & 14 & 14 & 17 & 6 \\
\hline Other & 8 & 9 & 7 & 9 & 10 & 8 & 5 & 7 & 0 \\
\hline Total & $\overline{100} \%$ & $\overline{99} \%$ & $\overline{101} \%$ & $\overline{99} \%$ & $\overline{100} \%$ & $\overline{101} \%$ & $\overline{100} \%$ & $\overline{100} \%$ & $\overline{100} \%$ \\
\hline \multicolumn{10}{|l|}{ Field of Employment ${ }^{\star \star}$} \\
\hline American Gov't/Public Law & $37 \%$ & $35 \%$ & $41 \%$ & $35 \%$ & $33 \%$ & $40 \%$ & $48 \%$ & $46 \%$ & $50 \%$ \\
\hline Public Policy & 7 & 8 & 5 & 7 & 8 & 5 & 7 & 7 & 6 \\
\hline Comparative Politics & 22 & 23 & 20 & 24 & 26 & 19 & 10 & 7 & 17 \\
\hline International Relations & 22 & 25 & 14 & 24 & 27 & 15 & 12 & 12 & 11 \\
\hline Public Administration & 8 & 6 & 12 & 7 & 6 & 10 & 9 & 2 & 22 \\
\hline Political Theory & 13 & 14 & 8 & 13 & 15 & 8 & 10 & 10 & 11 \\
\hline Methodology & 6 & 7 & 5 & 6 & 6 & 5 & 9 & 10 & 6 \\
\hline Other & 12 & 12 & 10 & 11 & 11 & 10 & 17 & 20 & 11 \\
\hline
\end{tabular}

*All valid responses.

** Respondents could select all fields that apply in this table and in all the tables reporting on field of employment or field in which sought employment.

positions. Respondents who have non-academic positions reported median salaries comparable to the highest academic salaries.

Table 4 records responses to questions on the availability and usefulness of specific sources of information and assistance in finding employment for all respondents and according to their employment status and type of primary job. The sources of information are organized broadly under three categories: Ph.D. de- partment and institution, professional networks, and the APSA. Respondents could check all sources of assistance that were available and that they found useful. The two sources of job information and assistance available to both employed and unemployed placement candidates, and to around 9 out of 10 respondents, were their dissertation advisors and the Personnel Service Newsletter (PSN). Other sources of employment information and assis- tance available to $50 \%$ to $60 \%$ of these placement candidates included the department's graduate director and placement director, APSA's Annual Meeting Placement Service, regional political science association meetings and placement services, and peers and colleagues at their own university. Nearly as many respondents, but more of the men than women, indicated that peers and colleagues at other universities were available to assist them in their 


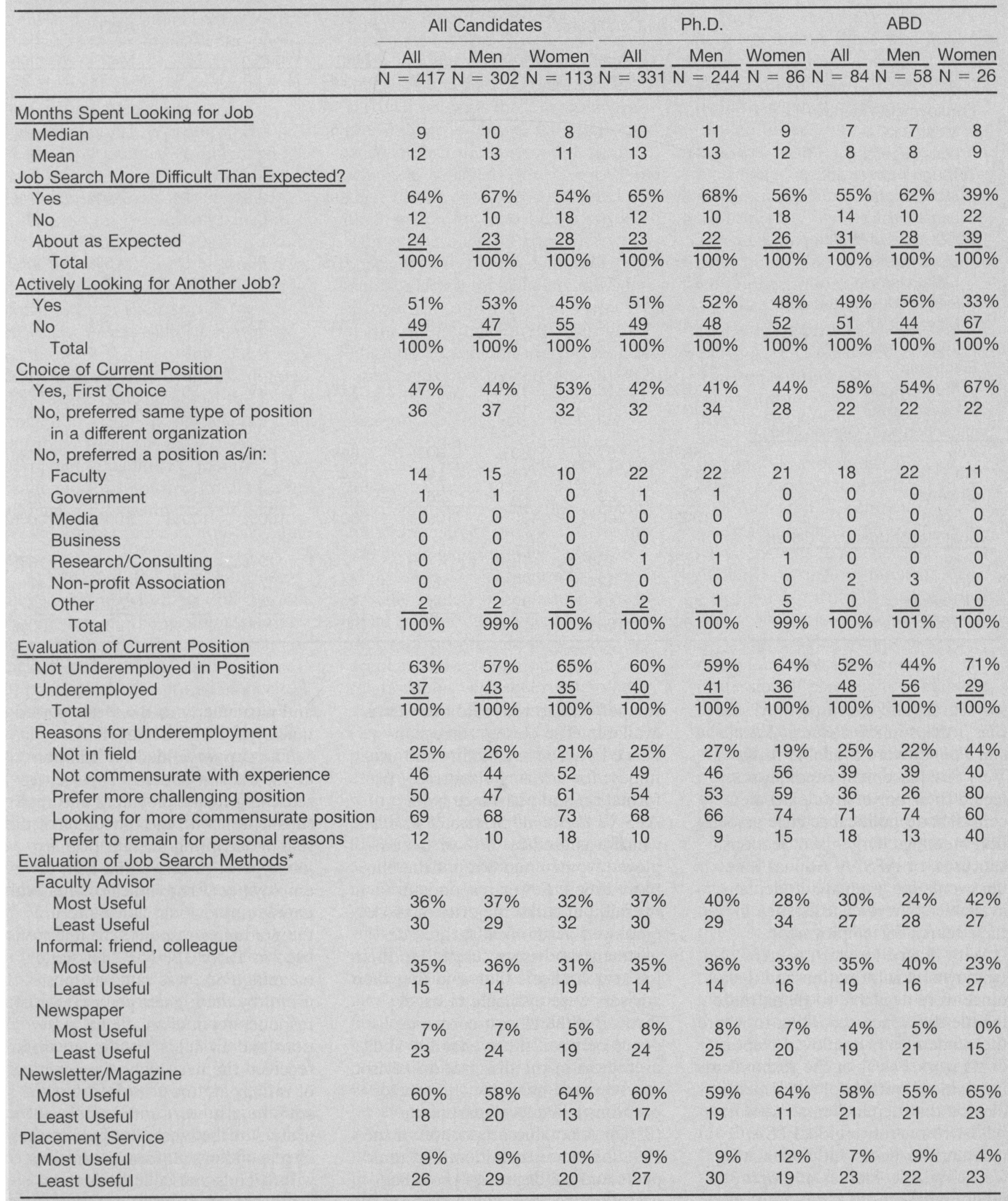

${ }^{*}$ Respondents could select two sources in each category-most useful and least useful-to evaluate job search methods in this table and in all tables reporting on their evaluation of job search methods. 
TABLE 3B 1996 Placement Candidates: Job Search and Satisfaction (continued)

\begin{tabular}{|c|c|c|c|c|c|c|c|c|c|}
\hline & \multicolumn{3}{|c|}{ All Candidates } & \multicolumn{3}{|c|}{ Ph.D. } & \multicolumn{3}{|c|}{$\mathrm{ABD}$} \\
\hline & All & Men & Women & All & Men & Women & All & Men & Women \\
\hline & $\bar{N}=417$ & $\bar{N}=302$ & $\bar{N}=113$ & $\bar{N}=331$ & $\bar{N}=244$ & $\bar{N}=86$ & $\bar{N}=84$ & $\bar{N}=58$ & $\bar{N}=26$ \\
\hline \multicolumn{10}{|c|}{ Employment Agency } \\
\hline Most Useful & $1 \%$ & $1 \%$ & $0 \%$ & $0 \%$ & $0 \%$ & $0 \%$ & $1 \%$ & $2 \%$ & $0 \%$ \\
\hline Least Useful & 6 & 8 & 3 & 7 & 9 & 2 & 2 & 3 & 0 \\
\hline \multicolumn{10}{|c|}{ Through Former Job } \\
\hline Most Useful & $8 \%$ & $8 \%$ & $9 \%$ & $9 \%$ & $8 \%$ & $9 \%$ & $8 \%$ & $9 \%$ & $8 \%$ \\
\hline Least Useful & 4 & 6 & 0 & 5 & 7 & 0 & 1 & 2 & 0 \\
\hline \multicolumn{10}{|c|}{ Sent Unsolicited Vita } \\
\hline Most Useful & $6 \%$ & $6 \%$ & $7 \%$ & $7 \%$ & $6 \%$ & $8 \%$ & $5 \%$ & $5 \%$ & $4 \%$ \\
\hline Least Useful & 15 & 17 & 11 & 14 & 15 & 9 & 20 & 22 & 15 \\
\hline \multicolumn{10}{|c|}{ Received Unsolicited Offer } \\
\hline Most Useful & $4 \%$ & $4 \%$ & $4 \%$ & $3 \%$ & $3 \%$ & $4 \%$ & $6 \%$ & $7 \%$ & $4 \%$ \\
\hline Least Useful & 5 & 7 & 1 & 6 & 9 & 0 & 0 & 0 & 0 \\
\hline \multicolumn{10}{|l|}{ Electronic } \\
\hline Most Useful & $16 \%$ & $18 \%$ & $10 \%$ & $15 \%$ & $17 \%$ & $8 \%$ & $20 \%$ & $22 \%$ & $15 \%$ \\
\hline Least Useful & 13 & 13 & 12 & 12 & 12 & 9 & 16 & 16 & 15 \\
\hline \multicolumn{10}{|c|}{ Satisfaction with Career Choice } \\
\hline Yes & $58 \%$ & $57 \%$ & $60 \%$ & $60 \%$ & $59 \%$ & $62 \%$ & $49 \%$ & $47 \%$ & $54 \%$ \\
\hline No & 14 & 14 & 14 & 14 & 14 & 15 & 14 & 15 & 11 \\
\hline Uncertain & $\underline{28}$ & $\underline{29}$ & $\underline{26}$ & $\underline{26}$ & $\underline{27}$ & $\underline{23}$ & 37 & 38 & 35 \\
\hline Total & $\overline{100} \%$ & $\overline{100} \%$ & $\overline{100} \%$ & $\overline{100} \%$ & $\overline{100} \%$ & $\overline{100} \%$ & $\overline{100} \%$ & $\overline{100} \%$ & $\overline{100} \%$ \\
\hline \multicolumn{10}{|c|}{ Would Recommend to Others } \\
\hline Yes & $17 \%$ & $16 \%$ & $19 \%$ & $17 \%$ & $17 \%$ & $19 \%$ & $16 \%$ & $14 \%$ & $19 \%$ \\
\hline No & 41 & 42 & 39 & 42 & 44 & 37 & 38 & 34 & 46 \\
\hline Uncertain & 42 & 42 & 42 & 41 & 39 & 44 & 46 & $\underline{52}$ & $\underline{35}$ \\
\hline Total & $\overline{100} \%$ & $\overline{100} \%$ & $\overline{100} \%$ & $\overline{100} \%$ & $\overline{100} \%$ & $\overline{100} \%$ & $\overline{100} \%$ & $\overline{100} \%$ & $\overline{100} \%$ \\
\hline
\end{tabular}

job search, and over one-third said that articles in PS: Political Science and Politics were available to them. Very few placement candidates selected their university's placement center, state political science association meetings, Organized Sections, caucuses, or APSA's Annual Meeting events for graduate students as available sources of assistance in their search for employment.

With regard to which sources of employment information and assistance were available to them, there is little difference according to where the academically employed respondents work Fewer of the respondents in positions outside of academia indicated that departmental advisors, APSA resources, regional PSA meetings, or peers and colleagues were available sources of employment assistance.

The percentage of respondents who found a source of employment assistance useful is always lower than the percentage who said that it was available. The closest correspondence between availability and usefulness for any single source of information and assistance is for APSA's Personnel Service Newsletter, which was used by $75 \%$ of the employed women and $80 \%$ of the employed men. Fewer respondents overall, but still a majority of those employed academically, rated departmental advisors "useful" to their job search efforts than said that their advisers were available to assist them. But the closest correspondence between the availability and usefulness of the dissertation advisor was reported by women who held positions in Ph.D. departments $(83 \%)$. A notable proportion of the 1996 job candidates identified their peers and colleagues as providing useful information and assistance for their employment search. Networking was a significant source of assistance to political science graduates, and particularly to those not placed quickly in Ph.D. departments.

The survey yielded information about the respondents' experiences searching for employment and their satisfaction with the outcomes of the search according to their primary job, type of position, and field of employment. The indicators for evaluating employment assistance are the graduates responses to questions used in Table 3B. The "newsletter," meaning PSN, was rated as most useful by the highest percentages of respondents in all academic positions and all fields. Faculty advisors received the next highest percentage of ratings as "most useful," but the advisors also were rated as "least useful," often by similar percentages of respondents. Informal contacts with friends and colleagues were again one of the most useful job search methods regardless of type of job or position.

An examination of the respon- 
dents' employment search according to their primary jobs, categorized in terms of type of academic department and non-academic employment finds that those in academic positions spent less time looking for employment (www.apsanet.org/ professional/placement/ webtable2.html). Women placed in Ph.D. department took longer to get their jobs than did men placed in Ph.D. departments, but the reverse is the case for the respondents employed in masters and undergraduate departments. More of the women than men placed in academic positions said that their search for employment was as difficult as expected: more of the men said that it was more difficult. The overall finding that higher percentages of the women in faculty positions than men in similar positions have full-time permanent positions is manifest for academically employed graduates in all types of departments but is reversed among those in non-academic jobs.

As expected, the doctoral graduates' assessments of the difficulty of the job search, the usefulness of faculty advisors, satisfaction with their current position, and with a career in political science are all associated positively with the permanence of their positions and with having fulltime rather than part-time positions (www.apsanet.org/professional/ placement/webtable3.html). Women took into account personal objectives as well as professional objectives and possibly were more likely to compromise in accepting a position than men, as a slightly higher percentage of women than men reported taking a job outside of their major field and $16 \%$ more women than men who considered themselves underemployed selected "personal reasons" for choosing to stay in their current position.

The employment search experiences of the 1996 doctoral graduates were related to their academic field as well (www.apsanet.org/professional/ placement/webtable4.html). Higher percentages of those in the smallersized fields of public administration (70\%), public policy (64\%), and methodology (64\%) were in tenure- track positions than were respondents in comparative politics (51\%), international relations $(42 \%)$, and political theory (39\%). As could be anticipated, there is a similar association between the respondents' major fields and their job and career satisfaction, with those in comparative politics, international relations, and political theory, overall, somewhat less satisfied with their jobs and their career choice. With respect to their search for jobs, higher percentages of the doctoral graduates who specialized in the smaller-sized subfields selected their faculty advisors as one of two of the most useful methods of employment assistance. Placement candidates in the smallersized fields may be better positioned to get the attention of advisors and mentors. Friends and colleagues were considered most useful in the job search particularly by men in the field of political theory (54\%).

In addition to evaluating employment and career satisfaction broadly, the employed graduates indicated their levels of satisfaction with such specific aspects of their current positions as salary and benefits, opportunities for promotion, personal development and recognition, their relationships with supervisors and colleagues, and working conditions (www.apsanet.org/professional/ placement/webtable5.html). Most employed graduates are satisfied with many aspects of their current positions. Salary is the target of lesser satisfaction relative to other aspects of employment. In contrast, majorities of the employed graduates were satisfied with their relationships with colleagues and supervisors (department chairs) and working conditions. While political science graduates placed in all temporary positions are understandably not satisfied with their opportunities for promotion and, to a lesser degree, with their opportunities for personal development and recognition, there is little difference in overall satisfaction with the other personal and professional aspects of their jobs between these graduates and those in full-time permanent positions and those in non-academic positions. This finding is evidence that there are supportive professional departmental climates for faculty who get temporary appointments.

There are no sharp distinctions to be made among those who hold academic position in terms of their primary job by type of department, particularly when the responses are divided broadly in terms of satisfied and dissatisfied. Comparing levels of job satisfaction for women and men placed in the same type of academic departments, slightly higher percentages of women than men in Ph.D. departments indicated satisfaction with opportunities for promotion and recognition. Women and men placed in undergraduate departments have comparable levels of satisfaction with all aspects of their current positions, with slightly higher percentages of women than men satisfied with their opportunities for personal development. Since a higher proportion of women than men indicated a preference for placement in an undergraduate department, this difference may be influenced by such preference.

An indicator of job satisfaction, as well as stability, is whether the employed graduates were seeking another job (www.apsanet.org/ professional/ placement/webtable 7. html). Not surprisingly, fewer of the academically employed doctoral graduates who held a permanent position, which coincides for the most part with a tenure-track position, reported not seeking another position. Among all employed respondents, $27 \%$ in full-time positions and $85 \%$ in full-time temporary positions reported that they were actively seeking another job. Among those who were academically employed, $17 \%$ of the respondents in a tenure-track position and $84 \%$ of those in a non-tenure-track position said that they are actively seeking another job. Other factors associated with not seeking another position were the respondents' preferences for their current position and evaluations as to whether their jobs match their skills, fields, and experience. Some three times more of the graduates whose current positions were their first choice than those for whom they were not are not seeking 


\section{TABLE 4}

Availability and Usefulness to 1966 Placement Candidates of Specific Sources of Information and Assistance in Their Job Search and Their Employment Status and Type of Job*

\begin{tabular}{|c|c|c|c|c|c|c|c|c|c|}
\hline & \multirow{2}{*}{\multicolumn{3}{|c|}{ All Placement Candidates }} & \multicolumn{6}{|c|}{ Employment Status } \\
\hline & & & & \multicolumn{3}{|c|}{ Employed } & \multicolumn{3}{|c|}{ Not Employed } \\
\hline & All & Men & Women & All & Men & Women & All & Men & Women \\
\hline & $\bar{N}=417$ & $\bar{N}=302$ & $\overline{N=113}$ & $\bar{N}=359$ & $\bar{N}=261$ & $\bar{N}=97$ & $\overline{N=57}$ & $\bar{N}=41$ & $\bar{N}=16$ \\
\hline \multicolumn{10}{|c|}{ Sources of Information and Assistance* } \\
\hline \multicolumn{10}{|c|}{ Ph.D. Department and Institution } \\
\hline \multicolumn{10}{|c|}{ Dissertation Advisor } \\
\hline Available & $91 \%$ & $92 \%$ & $89 \%$ & $91 \%$ & $93 \%$ & $88 \%$ & $93 \%$ & $90 \%$ & $100 \%$ \\
\hline Useful & 61 & 60 & 63 & 64 & 64 & 63 & 46 & 39 & 63 \\
\hline \multicolumn{10}{|c|}{ Graduate Director } \\
\hline Available & $59 \%$ & $60 \%$ & $57 \%$ & $59 \%$ & $61 \%$ & $56 \%$ & $60 \%$ & $59 \%$ & $63 \%$ \\
\hline Useful & 21 & 20 & 22 & 20 & 20 & 20 & 26 & 22 & 38 \\
\hline \multicolumn{10}{|c|}{ Placement Director } \\
\hline Available & $53 \%$ & $55 \%$ & $46 \%$ & $54 \%$ & $56 \%$ & $45 \%$ & $49 \%$ & $49 \%$ & $50 \%$ \\
\hline Useful & 22 & 24 & 17 & 20 & 24 & 17 & 26 & 27 & 25 \\
\hline \multicolumn{10}{|c|}{ University Placement Center } \\
\hline Available & $27 \%$ & $29 \%$ & $24 \%$ & $27 \%$ & $30 \%$ & $21 \%$ & $30 \%$ & $24 \%$ & $44 \%$ \\
\hline Useful & 6 & 6 & 6 & 6 & 7 & 4 & 7 & 2 & 19 \\
\hline \multicolumn{10}{|c|}{ Professional Networks } \\
\hline \multicolumn{10}{|c|}{$\begin{array}{l}\text { Regional PSA Meetings \& Placement } \\
\text { Service }\end{array}$} \\
\hline Available & $59 \%$ & $61 \%$ & $54 \%$ & $60 \%$ & $61 \%$ & $59 \%$ & $53 \%$ & $63 \%$ & $25 \%$ \\
\hline Useful & 13 & 12 & 17 & 14 & 12 & 20 & 11 & 15 & 0 \\
\hline \multicolumn{10}{|c|}{ State PSA Meetings } \\
\hline Available & $13 \%$ & $14 \%$ & $10 \%$ & $13 \%$ & $13 \%$ & $10 \%$ & $12 \%$ & $15 \%$ & $6 \%$ \\
\hline Useful & 1 & 2 & 0 & 2 & 2 & 0 & 0 & 0 & 0 \\
\hline \multicolumn{10}{|c|}{ Organized Sections } \\
\hline Available & $19 \%$ & $20 \%$ & $17 \%$ & $18 \%$ & $19 \%$ & $16 \%$ & $26 \%$ & $27 \%$ & $25 \%$ \\
\hline Useful & 3 & 3 & 3 & 3 & 3 & 3 & 4 & 5 & 0 \\
\hline \multicolumn{10}{|c|}{ Caucus/Organized Group } \\
\hline Available & $7 \%$ & $5 \%$ & $12 \%$ & $7 \%$ & $5 \%$ & $12 \%$ & $4 \%$ & $2 \%$ & $6 \%$ \\
\hline Useful & 1 & 1 & 2 & 1 & 0 & 2 & 2 & 2 & 0 \\
\hline \multicolumn{10}{|c|}{ Peers/colleagues at Own University } \\
\hline Available & $57 \%$ & $60 \%$ & $51 \%$ & $59 \%$ & $60 \%$ & $56 \%$ & $49 \%$ & $59 \%$ & $25 \%$ \\
\hline Useful & 32 & 33 & 30 & 34 & 34 & 32 & 23 & 24 & 19 \\
\hline \multicolumn{10}{|c|}{$\begin{array}{l}\text { Peers/colleagues at Other } \\
\text { Institutions }\end{array}$} \\
\hline Available & $48 \%$ & $51 \%$ & $41 \%$ & $49 \%$ & $51 \%$ & $42 \%$ & $44 \%$ & $49 \%$ & $31 \%$ \\
\hline Useful & 31 & 32 & 27 & 32 & 33 & 27 & 23 & 22 & 25 \\
\hline \multicolumn{10}{|c|}{$\begin{array}{l}\text { American Political Science Association } \\
\text { Personnel Service Newsletter }\end{array}$} \\
\hline Available & $91 \%$ & $92 \%$ & $89 \%$ & $91 \%$ & $91 \%$ & $89 \%$ & $95 \%$ & $95 \%$ & $94 \%$ \\
\hline Useful & 78 & 80 & 75 & 79 & 79 & 76 & 79 & 83 & 69 \\
\hline \multicolumn{10}{|c|}{ Annual Meeting Placement Service } \\
\hline Available & $60 \%$ & $59 \%$ & $62 \%$ & $61 \%$ & $60 \%$ & $63 \%$ & $60 \%$ & $61 \%$ & $56 \%$ \\
\hline Useful & 12 & 10 & 18 & 12 & 10 & 18 & 14 & 12 & 19 \\
\hline \multicolumn{10}{|c|}{ Reports, Articles in PS } \\
\hline Available & $37 \%$ & $37 \%$ & $37 \%$ & $37 \%$ & $37 \%$ & $37 \%$ & $40 \%$ & $42 \%$ & $38 \%$ \\
\hline Useful & 18 & 16 & 20 & 17 & 15 & 20 & 23 & 22 & 25 \\
\hline $\begin{array}{r}\text { Annual Mee } \\
\text { Student }\end{array}$ & & & & & & & & & \\
\hline Available & $13 \%$ & $14 \%$ & $12 \%$ & $13 \%$ & $13 \%$ & $12 \%$ & $19 \%$ & $24 \%$ & $6 \%$ \\
\hline Useful & 0 & 0 & 0 & 0 & 0 & 0 & 0 & 0 & 0 \\
\hline
\end{tabular}

*Respondents could select all sources that apply in this table. 
Type of Primary Job

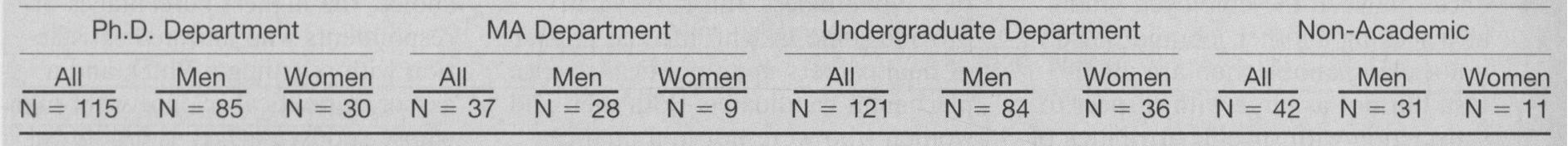

\begin{tabular}{|c|c|c|c|c|c|c|c|c|c|c|c|}
\hline $93 \%$ & $93 \%$ & $93 \%$ & $97 \%$ & $100 \%$ & $89 \%$ & $93 \%$ & $93 \%$ & $92 \%$ & $83 \%$ & $87 \%$ & $73 \%$ \\
\hline 70 & 65 & 83 & 62 & 68 & 44 & 68 & 71 & 58 & 43 & 42 & 46 \\
\hline $64 \%$ & $65 \%$ & $63 \%$ & $62 \%$ & $61 \%$ & $67 \%$ & $60 \%$ & $58 \%$ & $64 \%$ & $48 \%$ & $52 \%$ & $36 \%$ \\
\hline 28 & 28 & 27 & 16 & 14 & 22 & 21 & 20 & 22 & 5 & 7 & 0 \\
\hline $57 \%$ & $61 \%$ & $47 \%$ & $51 \%$ & $61 \%$ & $22 \%$ & $59 \%$ & $57 \%$ & $61 \%$ & $38 \%$ & $45 \%$ & $18 \%$ \\
\hline 29 & 33 & 17 & 22 & 25 & 11 & 23 & 24 & 22 & 12 & 16 & 0 \\
\hline $24 \%$ & $28 \%$ & $13 \%$ & $32 \%$ & $29 \%$ & $44 \%$ & $26 \%$ & $27 \%$ & $25 \%$ & $33 \%$ & $39 \%$ & $18 \%$ \\
\hline 7 & 7 & 7 & 8 & 11 & 0 & 5 & 6 & 3 & 5 & 3 & 9 \\
\hline $64 \%$ & $59 \%$ & $77 \%$ & $60 \%$ & $64 \%$ & $44 \%$ & $61 \%$ & $63 \%$ & $58 \%$ & $48 \%$ & $45 \%$ & $55 \%$ \\
\hline 17 & 12 & 30 & 11 & 11 & 11 & 14 & 12 & 19 & 7 & 7 & 9 \\
\hline $10 \%$ & $11 \%$ & $7 \%$ & $11 \%$ & $11 \%$ & $11 \%$ & $13 \%$ & $16 \%$ & $8 \%$ & $12 \%$ & $7 \%$ & $27 \%$ \\
\hline 2 & 2 & 0 & 0 & 0 & 0 & 3 & 4 & 0 & 0 & 0 & 0 \\
\hline $22 \%$ & $26 \%$ & $10 \%$ & $19 \%$ & $21 \%$ & $11 \%$ & $17 \%$ & $13 \%$ & $25 \%$ & $17 \%$ & $16 \%$ & $18 \%$ \\
\hline 4 & 5 & 0 & 0 & 0 & 0 & 3 & 1 & 8 & 0 & 0 & 0 \\
\hline $5 \%$ & $2 \%$ & $13 \%$ & $5 \%$ & $0 \%$ & $22 \%$ & $8 \%$ & $6 \%$ & $14 \%$ & $7 \%$ & $7 \%$ & $9 \%$ \\
\hline 1 & 0 & 3 & 0 & 0 & 0 & 2 & 1 & 3 & 0 & 0 & 0 \\
\hline $63 \%$ & $62 \%$ & $63 \%$ & $60 \%$ & $64 \%$ & $44 \%$ & $60 \%$ & $61 \%$ & $56 \%$ & $38 \%$ & $36 \%$ & $46 \%$ \\
\hline 38 & 38 & 40 & 27 & 36 & 0 & 36 & 33 & 39 & 24 & 23 & 27 \\
\hline $59 \%$ & $60 \%$ & $57 \%$ & $51 \%$ & $61 \%$ & $22 \%$ & $45 \%$ & $48 \%$ & $36 \%$ & $33 \%$ & $26 \%$ & $55 \%$ \\
\hline 42 & 42 & 40 & 38 & 50 & 0 & 25 & 26 & 19 & 24 & 16 & 46 \\
\hline $93 \%$ & $93 \%$ & $93 \%$ & $100 \%$ & $100 \%$ & $100 \%$ & $93 \%$ & $93 \%$ & $94 \%$ & $74 \%$ & $74 \%$ & $73 \%$ \\
\hline 82 & 85 & 73 & 89 & 93 & 78 & 88 & 85 & 94 & 52 & 52 & 55 \\
\hline $64 \%$ & $60 \%$ & $73 \%$ & $70 \%$ & $68 \%$ & $78 \%$ & $63 \%$ & $62 \%$ & $64 \%$ & $45 \%$ & $52 \%$ & $27 \%$ \\
\hline 10 & 9 & 13 & 11 & 11 & 11 & 17 & 11 & 31 & 12 & 13 & 9 \\
\hline $37 \%$ & $34 \%$ & $47 \%$ & $57 \%$ & $57 \%$ & $56 \%$ & $40 \%$ & $41 \%$ & $36 \%$ & $17 \%$ & $19 \%$ & $9 \%$ \\
\hline 15 & 14 & 17 & 30 & 25 & 44 & 20 & 18 & 22 & 2 & 3 & 0 \\
\hline $10 \%$ & $9 \%$ & $13 \%$ & $30 \%$ & $36 \%$ & $11 \%$ & $9 \%$ & $7 \%$ & $14 \%$ & $10 \%$ & $13 \%$ & 0 \\
\hline 0 & 0 & 0 & 0 & 0 & 0 & 0 & 0 & 0 & 0 & 0 & 0 \\
\hline
\end{tabular}


another position. Nearly four times more of the respondents who consider themselves underemployed as those who do not are actively searching for another job. Differences between the employed graduates seeking another job and those not seeking another job are manifest, but not as large with respect to satisfaction with specific attributes of their current positions. While 35\% more of those not seeking another job said that they were satisfied with their choice of a career in political science than did those actively seeking another job, there is little difference between the two groups as to whether they would recommend the career to others.

What about the plans of the 1996 doctoral graduates who did not get jobs? (www.apsanet.org/professional/ placement/webtable8.html). Nearly one-half remained unemployed and one-fifth (but $38 \%$ of the women and $15 \%$ of the men) said that they would remain in school with a parttime job. A position in a Ph.D. department was preferred by more of the men than any other position. Equal percentages of the women selected a position in a Ph.D. department and in an undergraduate department $(31 \%)$. A higher percentage of the men than women said that they were considering a nonacademic position. More of the women were uncertain about any non-academic position. Relatively few of the unemployed placement candidates were definitely considering employment in non-academic positions. Among possible non-academic positions, those in government received the most mentions.

\section{Dual Careers and Employment in Political Science}

Over one-half of the 1996 doctoral graduates who participated in this study had to consider the career needs of a spouse or partner (www. apsanet.org/professional/placement/ webtable $9 . \mathrm{html}$ ). The graduates were asked about their dual-career status, and those with dual careers were asked whether their spouse or part- ner needed a job in political science, in another academic field, or in another profession. There were small numbers of respondents, particularly of women, in the dual-career categories. Nonetheless, this survey can provide some insight into the impact of dual careers upon political science placement candidates. Both men and women who were not in a dual-career situation reported a median time of 6 years to get their Ph.D., one year less than the median for dual-career couples. And, looking for a job also took longer for placement candidates who are in some dual-career situation. The candidates with dual careers in academia reported the lengthiest job search experiences-one-and-one-half years for men and one year for women. Dual-career couples in political science reported a less lengthy job search than other dual-career couples, perhaps attributable to their focusing on a specified and shared job market. The placement process may be more complicated when more than one academic department or professional network is involved. Another possibility is that the graduates with dual careers in political science were quicker to accept employment or compromise in doing so because their placement outcomes were less positive if gauged by whether they were seeking another job. A somewhat higher percentage of the respondents with dual careers in political science said they were actively looking for another position.

Men in a dual-career situation reported taking longer to find jobs than did women, and $78 \%$ of them found the job search more difficult than expected. But a higher percentage of men $(90 \%)$ than women $(69 \%)$ with dual careers in political science were employed. Higher percentages of women ( $86 \%$ to $100 \%$ ) in the other categories of dual careers, or not in any dual-career situation, were employed.

A higher percentage of the graduates with political science and academic dual careers were placed in Ph.D. departments, suggesting that departmental and institutional size facilitate accommodating dual-career needs. There is little difference at- tributable to dual-career status distinctions with respect to holding a tenure-track position and to whether the position was the candidate's first choice. With respect to career choice, the highest percentages of respondents who affirmed satisfaction with pursuing a Ph.D. and a career in political science were men whose spouse/partner is a political scientist $(70 \%)$ and women who did not have to consider the career needs of a spouse or partner $(74 \%)$. In contrast, only $38 \%$ of the women with dual careers in political science expressed satisfaction with their career choice, the lowest percentage for any category of respondents. Also, only $56 \%$ percent of the women with dual-career status in political science have their degree in hand, compared to $85 \%$ of the men in this situation and $83 \%$ of the women who did not have to consider the career of a spouse or partner. The experiences of the 1996 political science graduates with a need for dual-career placement in political science indicate that the difficulties of this situation are experienced more by women political scientists than by men and that faculty advisors be more attentive to the particular needs of this group of graduate students.

\section{What Doctoral Students Consider Important to Employers and in Securing Employment}

The political science Ph.D.s and ABDs seeking employment in 1996 who responded to this survey answered questions about what prospective employers consider important and identified the types of graduate training and placement assistance beneficial to the search for employment. Their answers, in Table 5 , confirm the primacy of scholarship, although this varies by type of primary job, and the need for further information and assistance to prepare for the job search.

Most of the academically employed respondents indicated they believed scholarly accomplishment and teaching skills were important to 
Academic Jobs of Employed 1996 Placement Candidates and Their Assessment of Attributes Employers Consider Important

Ph.D. Department
$\frac{\text { All }}{\mathrm{N}=115} \frac{\text { Men }}{\mathrm{N}=85} \frac{\text { Women }}{\mathrm{N}=30} \frac{\text { All }}{\mathrm{N}=37} \frac{\text { Men }}{\mathrm{N}=28} \frac{\text { Women }}{\mathrm{N}=9} \frac{\text { All }}{\mathrm{N}=121} \frac{\text { Men }}{\mathrm{N}=84} \frac{\text { Women }}{\mathrm{N}=36}$

Attributes Important to Employers

All Attributes Important to Employers

Scholarly Accomplishment and Promise

Teaching Skills and Promise

Quality of Graduate Training

$\begin{array}{lllll}94 \% & 92 \% & 100 \% & 89 \% & 89 \%\end{array}$

$\begin{array}{lll}84 & 79 & 97\end{array}$

$80 \quad 81 \quad 77$

89

Contribution to Faculty Diversity

40

38

47

65

51

$89 \%$
93

68

50

$89 \%$
78
56
56

$94 \%$

93

72

43

$96 \%$

94

73

73
37

$89 \%$

Attributes Considered to be

Most Important to Potential Employers

Scholarly Accomplishment and Promis

Teaching Skills and Promise

Quality of Graduate Training

Contribution to Faculty Diversity

Other

N/A

Total

\begin{tabular}{ccc}
$61 \%$ & $61 \%$ & $60 \%$ \\
8 & 7 & 10 \\
7 & 7 & 7 \\
4 & 5 & 0 \\
3 & 5 & 0 \\
$\frac{17}{100} \%$ & $\frac{15}{100} \%$ & $\frac{23}{100} \%$ \\
\hline
\end{tabular}

$40 \%$
11
5
8
8
$\frac{27}{99} \%$

$39 \%$
11
4
7
11
29
$101 \%$

$44 \%$
11
11
11
0
$\frac{22}{99} \%$

$39 \%$
35
3
3
4
$\frac{17}{101} \%$

\begin{tabular}{cc}
$41 \%$ & $33 \%$ \\
32 & 42 \\
2 & 3 \\
4 & 0 \\
5 & 3 \\
$\frac{17}{101} \%$ & $\frac{19}{100 \%}$ \\
\hline
\end{tabular}

employers. The quality of graduate training also was credited as being important. More women than men selected teaching skills and contribution to diversity as important considerations for employers. Lesser percentages of all of the respondents employed in non-academic or other types of jobs selected any of the possible attributes offered as important. Political science doctoral graduates' regard for the singular importance of scholarly accomplishments and promise to employers was demonstrated by their selection of this attribute as the one most important to potential employers by a margin of nearly 3 to 1 overall, regardless of employment status. But the ratio is a little more than 2 to 1 among the academically employed women, nearly one-quarter of whom identified teaching skills and promise as the most important attribute to employers.

Table 5 displays the academically employed respondents' assessments of what attributes employers consider important according to the type of department that hired them. The responses affirm the differences in institutional and departmental missions in higher education. By a ratio of at least 6 to 1 , the newly employed Ph.D. faculty identify scholarly promise and accomplishment as the most important attribute; among the faculty employed by M.A. institutions, the ratio is less, but still considerable at 4 to 1 . Nearly comparable percentages of the newly employed undergraduate faculty identified teaching and scholarship as important attributes. Among undergraduate faculty, higher percentages of men $(41 \%)$ than women $(33 \%)$ said scholarship was the most important attribute and higher percentages of women $(42 \%)$ than men said teaching was the most important attribute (32\%).

The 1996 Placement Candidates were asked three open-ended questions calling for reflection on the relationship between graduate training and getting hired. Their responses to each question are summarized in Table 6. First, these political science graduates identified the aspects of their Ph.D. training that they now consider to have been most useful in preparing them for employment as political scientists. Twenty-eight percent of their responses cited training in research, getting published and giving papers. This category in- cluded distinct references to research skills (9\%), publishing opportunities $(9 \%)$, conference presentations (7\%), and writing and defending a dissertation (3\%). Teacher training, experience and teaching skills received $26 \%$ of the responses, nearly as many as scholarship, signifying that preparation for undergraduate teaching in graduate school proved useful in the job search. One respondent expressed the relationship as "Publish to get noticed, teach to get hired." Fifteen percent of the responses cited assistance from graduate advisers and the department as useful. Another $15 \%$ of the responses referred to their graduate courses, with the most mentions given to training in specific skills, notably in methodology $(6 \%)$. Other aspects of graduate education, personal attributes, and experiences received $10 \%$ of the responses. Graduate school was dismissed as being of no value in finding a job by $6 \%$ of the responses to this question.

A second question invited comments on what these placement candidates did not have in graduate school that they now think would have been helpful in finding employment. Twenty-seven percent of the 
TABLE 6

\section{Placement Candidates' Comments on Graduate Training and the Job Search}

Aspects of Graduate Training and

Experiences Now Considered Most Useful in Finding Employment No. of responses $=436$
Training and Experiences Useful in Finding Employment but Missing in Graduate School

No. of responses $=323$
Information or Assistance Recommended to Help Graduate Students be Better Prepared to Look for Professional Employment No. of responses $=319$
Training in Scholarship, Research, and Publishing 28\%

Research/scholarly skills, training $9 \%$

Publishing, opportunities to publish, co-author $9 \%$

Presenting conference papers $7 \%$

Dissertation and its defense $3 \%$

Teaching Training, Experience, and Abilities 26\%

Assistance from Graduate Department and Advisors other than Research and Teaching Training 15\%

Active advisor/mentor $5 \%$

Practice job talks 4\%

Prestigious department faculty $3 \%$

Faculty contacts, interaction $2 \%$

Socialization into academic life 1\%

Types of Training, Fields 15\%

Quantitative analysis/methodology 6\%

Broad training 5\%

Other specified fields $4 \%$

Other Useful Attributes, Activities 10\%

Personal skills, attitudes, outlook $2 \%$

Networking 2\%

Peer support $1 \%$

Attending conferences 1\%

Degree completed 1\%

Additional degree 1\%

Internships 1\%

Little or Nothing At All Useful 6\%
Publishing Papers 27\%

Publishing conference papers, encouragement and assistance in publishing $20 \%$

Faculty co-author a publication $7 \%$

Teaching Training, Experience 11\%

Faculty Assistance in the Placement Process 25\%

Mentoring relationship $7 \%$

Placement director's assistance in job search $7 \%$

Faculty advisor's guidance in the job search $4 \%$

Better preparation for the job talk $4 \%$

More professional development $3 \%$

Specific Skills, Courses $14 \%$

Quantitative training 10\%

Broader training $2 \%$

Specified other course titles, skills, computer, proposal writing $2 \%$

More Prestigious Degree 4\%

More, Better Introduction to Job Market, Hiring Institutions, and Careers 18\%
Publishing $23 \%$

Publications $18 \%$

Conference and meeting papers 5\%

Teaching Experience $7 \%$

Department, Faculty Assistance 15\%

Advisors' mentoring, assistance 3\%

$\mathrm{Be}$ at top ranked department $4 \%$

Active assistance in the job search $2 \%$

Practical training for professional roles 3\%

Have fewer students on the job market 3\%

Specific Training 6\%

Quantitative training/methodology $4 \%$

Mentions of fields $2 \%$

More Information/preparation for Job Search and Market $7 \%$

Recommend Against Graduate School, Academic Career $11 \%$

Advice to Graduate Students 33\%

Network with recent Ph.D.s 5\%

Pay attention to non academic jobs $4 \%$

Be prepared for a long and even unsuccessful job search 3\%

Get work experience, internships 2\%

Get the Ph.D. 2\%

Belong to an affirmative action group $2 \%$

Personal qualities: persistence, aggressiveness, patience, flexibility, entrepreneurship, and personality $10 \%$

Attend job talks $1 \%$

Choose faculty, fields, dissertation topic carefully $1 \%$

Understand different types of colleges and universities $1 \%$

Use advertisements in Chronicle, PSN 1\% responses specified faculty assistance, encouragement, or partnerships in publishing. Faculty assistance in professional development and in securing employment accounted for $25 \%$ of the responses, and included mentoring (7\%), guidance in the job search from the placement director $(7 \%)$ and from their advisor $(4 \%)$, better preparation for the job talk (4\%) and more attention to professional develop- ment in their graduate program $(3 \%)$. More and better information about the job market, careers, and what different hiring institutions seek in a new employee received $18 \%$ of the responses. Only $11 \%$ of the respondents said that teaching preparation was missing in graduate school-suggesting that a larger proportion of the graduate students had some teaching experience than had advice and assistance in producing publications and giving presentations at professional conferences and/or on how to get started in a political science career. The desire for more quantitative training expressed by $10 \%$ of these graduates responses should be noted also by Ph.D. departments.

The last open-ended question invited the 1996 graduates to recommend what information or assistance would better prepare graduate stu- 
dents to search for employment. Once again, having publications and making presentations at conference received the most mentions $(23 \%)$. Over one-fifth of the recommendations called for various types of assistance from their advisors, $15 \%$ called for more help from their departments, and $7 \%$ asked for more information and better preparation in order to understand the job market and how to conduct the job search. Preparation for undergraduate teaching received another $7 \%$ of the responses. One-third of the responses to this questions recommend an array of specific activities and personal qualities, with networking among peers being the most prominent and reflecting the reliance on this activity by many of the 1996 graduates. Finally, and another expression of the difficulties experienced by a contingent of doctoral graduates, one in ten of the recommendations was that students be advised against pursuing a graduate degree and an academic career.

To sum up, the comments made by these members of the 1996 political science placement class are realistic assessments of the skills and experiences that employers, particularly academic employers, consider to be important and forthright statements about useful professional training. These graduates recommend that Ph.D. faculty and departments give doctoral students more information and assistance, especially in publishing and presenting research, and along with professional organizations, do more to prepare doctoral graduates for the realities of the job market and for the process and, frequently, less-than-optimal, outcome of the job search.

\section{Addressing the Placement Concerns and Recommendations of Political Science Graduates}

The difficulties that so many political science placement candidates encounter in finding employment are widely acknowledged. The survey of members of the 1996 placement class confirm the impact of these difficulties and the disappointments

\section{Appendix 1 \\ Survey Design and Procedures}

The survey of members of the 1996 placement class was accomplished with the assistance of $60 \%$ of all Ph.D. departments, including $76 \%$ of the 25 departments having the largest placement classes. In fall 1996 and winter 1997, these departments sent the Association the names and mailing addresses of their graduates who were seeking jobs in 1996. A total of 865 names and addresses were submitted; 829 questionnaires were delivered, of which 417 were completed and returned for a response rate of $50.3 \%$. The four-page questionnaire was designed to comport with the objectives of CPST's collaborative project and be compatible with the aggregate placement data that the APSA has been collecting annually since 1972 by surveying Ph.D. departments. Questions posed to the placement candidates asking for evaluations of job search methods and job satisfaction were adapted from those used by the American Psychological Association in its annual survey of Ph.D.s in psychology. The introduction to the survey promised departments and individual recipients anonymity. To further guarantee confidentiality, APSA contracted with Questar, a research firm working with other professional associations in the project, to prepare, distribute, and collect the questionnaires, code responses to the closed ended questions, and provide printouts summarizing responses to open ended question.

The survey was distributed in spring 1997, with follow up mailings in the summer. The $50.3 \%$ response rate is comparable to the response rate for the surveys conducted by other scientific societies participating in this project and considered to be quite good for a new survey of doctoral students. It is possible that the respondents were tied more closely to the profession than the nonrespondents: $75 \%$ of the respondents said they are APSA members. However, the high rate of affiliation with the Association can be attributed also to the requirement that subscribers to the Personnel Service Newsletter, which lists academic positions in political science, be APSA members.

experienced by a significant proportion of political science graduates in getting hired and in having to plan immediately to search for another job. These difficulties are being experienced by doctoral graduates in other academic disciplines and this phenomenon was an important factor in establishing the collaborative study of doctoral graduates of which the special survey of members of the 1996 placement class is one component. The findings of this survey should prompt political scientists to address and ameliorate the difficulties graduates are encountering as they seek professional employment. To initiate a discussion of how the profession might respond, a list of possible initiatives follows.

\section{Consider the Number of Ph.D.s}

While very few survey respondents said that there were too many political science doctoral graduates competing for jobs, the numbers deserve attention. According to the National Science Foundation's summary of science and engineering doctorates awarded from 1987-96, 928 doctorates were awarded in all fields of political science in 1996, an increase of $30 \%$ from 647 doctorates in 1987 , with the most rapid annual increases occurring in the last five years. These figures include degrees in international relations, public administration, and public policy along with degrees in political science/government. But the growth in the number of doctorates cannot be attributed to the inclusion of the three specialized fields. In 1996, 621 doctorates were awarded in political science/government compared with 404 doctorates awarded in 1987, an increase of 54\% in the discipline's doctorates in the past decade (Hill 1997, 10).

An increase in the numbers of doctoral graduates once seemed appropriate because of projections of a growth in academic positions from 1987-2012 (Bowen and Sousa 1989). 
Even though undergraduate student enrollment has increased, colleges and universities have not responded by expanding the numbers of tenuretrack positions and are not likely to do so. Tenure-track positions are declining and part-time faculty positions are increasing. One report estimates that only two-fifths of recent faculty appointments are to full-time tenure-track positions (Schuster 1998). In addition, there will not be a growth in academic positions due to retirements because very few faculty are planning to retire in the coming years (National Center for Educational Statistics 1998).

A good case can be made for expanding the number of doctoral graduates on the reasoning that all educational institutions, the economy, and society are well served by having greater numbers of highly trained professionals. But, if graduate departments and the profession take this position, attention should be given to the next possible initiative.

\section{Consider Professional Socialization}

Political science doctoral students anticipate pursuing -and, for the most part, are expected to pursue-academic careers in four-year colleges and universities. An academic career is the goal of graduate students in nearly all of the humanities disciplines and in most of the social sciences. With the number of new doctorates in political science exceeding the number of full-time tenure-track positions, and the Association's placement studies showing a small but increasing percentage of placement candidates taking jobs outside academia, shouldn't graduate departments and the profession train students for alternate careers and help place students in such careers? If so, the professional culture needs to be changed to one more supportive of political scientists pursuing non-faculty careers. In reality, this will be as difficult to accomplish as any cultural change; the singular primacy of academic careers has characterized political science since the 1950 s.

Nonetheless, in recognition of the realities of the job market, suggestions for facilitating doctoral students' pursuit of careers other than as college or university faculty are presented next. ${ }^{4}$

\section{Increase Employment Information and Networks}

The recommendations as to what would have helped them and would help future placement classes made by the 1996 doctoral graduates call for more information about the various roles and responsibilities of college faculty, the differing missions and contexts of higher education institutions and how these affect faculty roles, preparing for interviews and job talks in accord with these institutional differences, and moving

\section{Appendix 2}

Additional Tables Appearing on the APSA Website

Salaries, 1996 Placement Candidates Employed in the U.S. by Gender and Type of Position (www.apsanet.org/professional/placement/webtable1.html)

Type of Primary Job-Academic by Department and Non-Academic-of Employed 1996 Placement Candidates

(www.apsanet.org/professional/placement/webtable2.html)

Type of Position of Employed 1996 Placement Candidates-Full Time Permanent, Full-Time Temporary, Part-Time Permanent, Part-Time

Temporary - and Their Employment Search, Status, Satisfaction and Degree Status (www.apsanet.org/professional/placement/webtable3.html)

Field of Academic Employment of 1996 Placement Candidates and Their Employment Search, Status, Satisfaction, and Degree Status (www.apsanet.org/professional/placement/webtable4.html)

Satisfaction with Specific Current Position of Employed 1996 Placement Candidates (www.apsanet.org/professional/placement/webtable5.html)

Type of Primary Job and Tenure Status(Combined) of Academically Employed 1996 Placement Candidates

(www.apsanet.org/professional/placement/webtable6.html)

Newly Employed Political Scientists Who Are and Who Are Not Seeking Another Job: Degree and Employment Status, Employment and Career Satisfaction (www.apsanet.org/professional/placement/webtable7.html)

Employment Preferences, Plans, and Status of Unemployed 1996 Placement Candidates (www.apsanet.org/professional/placement/webtable8.html)

Dual-Career Status Among 1996 Placement Candidates, Their Employment Search, Status, Satisfaction, and Selected Attributes

(www.apsanet.org/professional/placement/webtable9.html)

Employment Status of 1996 Placement Candidates and Their Assessment of Attributes Employers Consider Important

(www.apsanet.org/professional/placement/webtable10.html) 
market and job search designed for graduate departments and for graduate students in order to determine whether APSA should produce comparable guides for political science programs and graduates (Gilbert 1997; MLA Committee on Professional Employment 1997; Showalter et al. 1996).

Departments could develop a collection of references on career options for their graduate students around which to organize meetings on professional development. Many Ph.D.granting universities have faculty development centers on campus that can assist departments in the preparation of future faculty. All such preparation should continue to feature training and experience in teaching undergraduate students, as this was acknowledged by the survey respondents to be an important contributing factor to getting a faculty position.

The respondents' own use of networking among colleagues and peers could be extended by graduate departments establishing continuing contacts with faculty in neighboring colleges and universities and with rosters of doctoral alumni. These contacts can be a useful source of information about careers in non-Ph.D. institutions and the work of non-Ph.D.-granting universities and colleges. Alumni Ph.D.s might be asked to advise graduate students about different careers and types of employers.

APSA's Annual Meeting programs and those of the regional and state political science associations often include a session on finding employment and pursuing careers in political science. These sessions could become more institutionalized by being scheduled each year at the same time and widely publicized to serve as occasions to pull together and distribute current information about the job market and practical guidance about identifying career objectives and strategies. Presentations at these sessions might be summarized for wider distribution.

\section{Facilitate Presentations and Publications}

The increased competition for faculty jobs has increased pressure on graduate students to publish and to give presentations. Ph.D. programs and graduate advisors are in the best position to respond to requests by many of the 1996 doctoral graduates that more be done. Organized sections might consider advising graduate student members about strategies and opportunities for conference presentations and publishing articles in specialized journals. The APSA could augment its Guide to Getting Published in Political Science Journals with information about the scholarly review process. Also, the APSA and the regional associations might consider hosting workshops for graduate students on how to prepare papers and give presentations at professional conferences.

\section{Electronic Communications}

A small percentage of the respondents to this survey $(16 \%)$ said that electronic sources of information about jobs proved useful. It is very likely that increasing use will be made of electronic references and communications. APSA's widely used Personnel Service Newsletter is now online (www. apsanet.org/PSN/), and the Association's web site will expand to include references on the profession and professional development. Although relatively few respondents said that Organized Sections and caucuses provided useful job search information, these groups might use their discussion lists to address the needs of doctoral graduates and newly employed faculty. Departmental web sites can also be used to facilitate networking among a department's doctoral alumni and graduate students.

\section{Conclusion}

The findings of the survey of 1996 political science doctoral graduates who were seeking employment confirm the difficulties of the job search and that a considerable proportion of graduates (over half of the respondents to the survey) continued to look for a position or for another position in the coming year. Their evaluations of the employment search and of what would assist in this search should lead to initiatives to inform and prepare political science Ph.D.s on how to establish their careers.

While this report has disclosed the disappointments and critical evaluations of many placement candidates, it is important to acknowledge that a considerable group of political science doctoral graduates do succeed in getting the positions they want, are pleased with the outcomes of their job search and choice of a profession, and satisfied with the information and assistance that they received from their faculty advisors and graduate departments. In addition, newly employed political scientists, whether they are in temporary or permanent positions, receive collegial support from colleagues and department chairs. The growth in Organized Sections, specialized journals, newsletters, and discussion lists and the vitality of the professional meetings of the national, regional, and state political science associations complement and augment departmental and collegial connections.

\section{Notes}

1. Jun Yin created the SPSS files for data analysis and prepared the tables for this report. Jun Yin and Polly Leonard coordinated the questionnaire preparation and survey with Questar Data Systems of Eagan, Minnesota. Catherine E. Rudder and Robert J.-P. Hauck made constructive comments on earlier drafts of this report.
2. APSA's Placement Surveys are based on aggregate data on placement candidates reported by Ph.D. departments. The report on the 1997 survey will appear in the December 1998 issue of PS: Political Science and Politics.

3. Several tables appear only in the online version of this report. A complete list of these tables is given in Appendix 2. The URLs for the online tables are included in the text and the Appendix.

4. This is an objective of the APSA's 1999 publication on "Career Choices in Political Science," a successor to Alternative Careers in Political Science (1984). 


\section{References}

Bowen, William G., and Julie Ann Sosa. 1989. Prospects for Faculty in the Arts and Sciences. Princeton: Princeton University Press.

Gaff, Jerry G., and Leo M. Lambert. 1996. "Socializing Future Faculty to the Values of Undergraduate Education." Change(July-August): 38 .

Gilbert, Sandra M. 1997. MLA Committee on Professional Employment: Final Report. New York: The Modern Language Association of America.
Hill, Susan T. 1997. Science and Engineering Doctoral Awards 1996. Washington, DC: National Science Foundation.

Mann, Sheilah. 1997. "Placement of Political Science Doctoral Students in 1996: Degrees Matter." PS: Political Science and Politics 30(3): $602-10$.

MLA Committee on Professional Employment. 1997. Evaluating the Mission, Size and Composition of Your Doctoral Programs. New
York: The Modern Language Association of America.

National Center for Education Statistics. 1997. Retirement and Other Departmental Plans of Instructional Faculty and Staff in Higher Education. Washington, DC: NCES.

Schuster, Jack. 1998. "Reconfiguring the Professoriate: An Overview" Academe 84:49-53.

Showalter, English et al. 1996. The MLA Guide to the Job Search. New York: The Modern Language Association of America.

\section{COUNTING \\ ON THE \\ LATINO VOTE \\ Latinos \\ as a New \\ Electorate \\ Louis DeSipio}

The book

"illuminates an array of important issues and does so thoughtfully. Its findings will be a benchmark in understanding Latino voting, its effect, and its development." - AmERICAN POLITICAL SCIENCE REVIEW

To understand American racial and ethnic minority group politics, social scientists have largely relied on a black-white paradigm. Louis DeSipio gives a more complex picture by drawing both on the histories of other ethnic groups and on up-to-date but underutilized studies of Hispanics' political attitudes, values, and behaviors.

Race, Ethnicity, and Politics $\$ 14.50$ paper

\section{THE} MODERATES' DILEMMA

Massive

Resistance to

School

Desegregation

in Virginia

Edited by

Matthew D. Lassiter and Andrew B. Lewis Foreword by

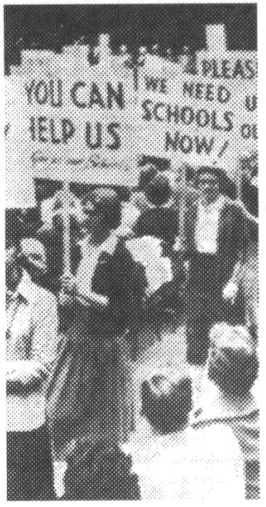

Paul M. Gaston

"Lassiter and Lewis and their colleagues have restored the sense of conflict over civil rights by depicting opposition to the movement in its full complexity and strength. Their picture is at once more interesting and more realistic than the one that now prevails in textbooks and academic conferences."-David L. Chapell, author of Inside Agitators: White Southerners in the Civil Rights Movement

$\$ 49.50$ cloth, \$18.50 paper

\section{THE MARTINSVILLE} SEVEN

Race, Rape, and Capital

Punishment

Eric W. Rise

"This is a valuable and memorable contribution to constitutional and civil rights history; it is well-written and thoroughly researched, and the study demonstrates how due process and equal protection arguments failed when placed against subtle, but very real, racial expectations within the southern legal system." - HisTORIAN Constitutionalism and Democracy $\$ 14.50$ paper

U N I V E R S I T Y PRESS OF VI R G I N I A

Box 3608

University Station

Charlottesville, VA 22903 TEL 804-924-3469 